\title{
FAMILY RELATIONS, PEER INFLUENCE, SPIRITUALITY AND DRUG USE AMONG STUDENTS IN ONE UNIVERSITY IN KINGSTON, JAMAICA
}

\author{
Howard Gough ${ }^{1}$, Samantha Longman-Mills², Winston De La Haye $e^{3}$, Robert Mann ${ }^{4}$, Bruna Brands ${ }^{5}$, Hayley \\ Hamilton $^{6}$, Maria da Glória Miotto Wright ${ }^{7}$, Francisco Cumsille ${ }^{8}$, Akwatu Khenti ${ }^{9}$
}

\footnotetext{
${ }^{1}$ MSc. Assistant Professor, Department of Psychology, International University of the Caribbean. Kingston, Jamaica. E-mail: misemiewasdere@yahoo.com

2 Ph.D. Associate Professor, Faculty of Medical Sciences, University of the West Indies, Mona Campus, Kingston, Jamaica. E-mail: samantha.longman02@uwimona.edu.jm

${ }^{3}$ Ph.D. Associate Professor, School of Medicine, University of the West Indies. Mona, Jamaica. E-mail: wdela@yahoo.com.

${ }^{4}$ Ph.D. Professor and Researcher, Centre for Addiction and Mental Health, CAMH, University of Toronto Toronto, Canada. E-mail: robert.mann@camh.ca

${ }^{5}$ Ph.D. Senior Scientist. Office of Research and Surveillance, Drug Strategy and Controlled Substances Programme, Health Canada and Public Health and Regulatory Policies, CAMH, University of Toronto. Toronto, Canada. E-mail: bruna.brands@camh.ca

${ }^{6}$ Ph.D. Investigator, CAMH, University of Toronto. Toronto, Canada. E-mail: hayley.hamilton@camh.ca

${ }^{7}$ Ph.D. Former Coordinator Educational Development Program Inter-American Drug Abuse Control Commission (CICAD), Secretariat for Multidimensional Security. Washington, USA. E-mail: gloriamiottowright@gmail.com

${ }^{8} \mathrm{Ph}$.D. Director Interamerican Drug Observatory, CICAD, Secretariat for Multidimensional Security at Organization of American States. Washington, USA. E-mail: fcumsille@oas.org

${ }^{9}$ Doctoral Student. Director, Office of Transformative Global Health, CAMH. Toronto, Canada. E-mail: akwatu.khenti@camh.ca
}

ABSTRACT: This study seeks to illuminate the relationship between family relations, peer influence, spirituality and drug use among students in one university in Kingston, Jamaica. A cross-sectional survey design was employed to collect quantitative data from 335 undergraduate university students, using self-report questionnaires. The sample consisted of 335 students ( $69 \%$ male and $31 \%$ female) between the ages $18-24$ years. $77.6 \%$ of the sample reported drug use within the past year. A significant positive correlation was identified between past year cannabis use and having dysfunctional and stressful family relationships ( $\mathrm{p}<.05)$; and negative correlations between past year alcohol, tobacco and cannabis use and positive peer influence $(p<.05)$ as well as higher levels of spirituality $(p<.01)$. A connected family relationship was a protective factor against cannabis use, while positive peer influence and high levels of spirituality are protective factors against alcohol, tobacco and cannabis use among the students who participated in this study.

DESCRIPTORS: Street drugs. Family relations. Friends. Spirituality.

\section{RELACIONES FAMILIARES, INFLUENCIA DE PARES, ESPIRITUALIDAD Y CONSUMO DE DROGAS ENTRE ESTUDIANTES EN UNA UNIVERSIDAD EN KINGSTON, JAMAICA}

RESUMEN: Este estudio busca clarear la relacion entre las relaciones familiares, la influencia de los pares, la espiritualidad y el uso de drogas en estudiantes de una Universidad en Kingston, Jamaica. Es un estudio de corte transversal utilizando datos cuantitativos de 335 estudiantes del pregrado, utilizando un cuestionario llenado por los estudiantes. La muestra fue compuesta de 335 estudiantes (69\% sexo masculino y 31\% sexo femenino) entre las idades de 18-24 anos. Los 77.6\% de los estudiantes de la muestra informaran ter utilizado drogas en el ano anterior. Una correlaccion positiva fue identificada entre el uso de cannabis en el ano anterior y tener una relacion familiar disfunccional y estresante $(p<.05)$; y correlaciones negativas entre el uso en el ano anterior de alcohol, fumar e cannabis y positive para influencia de pares $(\mathrm{p}<.05)$, bien como para niveles alto de espiritualidad $(\mathrm{p}<.01)$. Una relacion familiar buena fue un factor protetor contra el uso de cannabis, encuanto la influencia positiva de pares y alto nivel de espiritualidad fueran factores positivos contra el uso de alcohol, fumar, y cannabis entre estudiantes que participaran en la investigacion.

DESCRIPTORES: Drogas ilícitas. Relaciones familiares. Amigos. Espiritualidad. 


\section{RELAÇÕES FAMILIARES, INFLUÊNCIA DOS PARES, ESPIRITUALIDADE E USO DE DROGAS ENTRE ESTUDANTES DE UMA UNIVERSIDADE EM KINGSTON, JAMAICA}

RESUMO: Tem por objetivo analisar as relações familiares e a influência dos grupos de amigos, a espiritualidade e o uso de drogas em estudantes de uma Universidade en Kingston, Jamaica. É um estudo de corte transversal, utilizando dados quantitativos de 335 estudantes de graduação, utilizando um questionário. A amostra de 355 estudantes teve $69 \%$ do sexo masculino e $31 \%$ do sexo feminino, entre as idades de 18-24 anos. Os 77.6\% de estudantes da amostra informaram ter utilizado drogas no ano anterior. Uma correlação positiva foi encontrada entre o uso de cannabis no ano anterior e ter uma relação familiar disfucional e estressante ( $p<.05)$; e correlações negativas entre o uso anterior de alcool, fumar e cannabis $(\mathrm{p}<.01)$. Uma relação familiar boa mostrou ser um fator, protetor contra o uso de cannabis, enquanto a influência positiva de amigos e o alto nivel de espiritualidade foram fatores positivos contra o uso de alcool, fumar e cannabis entre estudantes que participaram na pesquisa.

DESCRITORES: Drogas ilícitas. Relações familiares. Amigos. Espiritualidade.

\section{INTRODUCTION}

Jamaica is a producer, exporter and consumer of licit and illicit drugs such as alcohol, tobacco and cannabis. Jamaica has the largest cannabis market share within the Caribbean, generating over US\$210 million, approximately half of the region's market share and about 2.8 per cent of the country's registered gross domestic product. ${ }^{1}$ The island's geographic location in the Northern Caribbean and its numerous legitimate commercial air and sea links with North America and Europe, makes it an ideal trans-shipment point for illicit drugs originating in South America. There are huge profits associated with the acquisition and distribution of illicit drugs in Jamaica, and coupled with the challenging economic climate of the island, ${ }^{2}$ it has resulted in the widespread availability of illicit drugs. The cost for illicit drugs in Jamaica is significantly below international costs. A kilogram of $90 \%$ pure cocaine hydrochloride can be acquired in Jamaica for approximately US\$3,000 and may be sold in Britain for as high as 98,000 Euros or US $\$ 122,000 .{ }^{3}$ The easy availability of illicit drugs in Jamaica is a serious concern as research has shown that overall drug use tends to be greater in countries where there is a perception of easy access to illicit drugs. ${ }^{4} \mathrm{~A}$ 2002 national survey in Jamaica identified that one in every five persons had used an illicit drug during their lifetime, with young adults between the ages 18-24, reporting the highest consumption levels; with cannabis accounting for approximately $99 \%$ of all illicit drugs used. ${ }^{5}$ Additionally, the lifetime prevalence of alcohol and tobacco use was reported as being $57.5 \%$ and $22.6 \%$ respectively. This high level of drug use highlights the need to understand the protective as well as risk factors for both illicit and licit drug use. However, there is a paucity of studies examining the risk factors associated with drug use in Jamaica. Therefore, this study seeks to fill the gap in the literature particularly as it relates to the effect of spirituality, family and peer relations on drug use.

Social relationships are known to influence drug use, with the most influential relationships being those with one's family and peers. The typical Jamaican family tends to be a matriarchal extended family, with the father having a visiting relationship with the family. ${ }^{6}$ A cohesive and connected family is anticipated to act in a protective manner against drug use, while a distant and dysfunctional family may predispose young adults to drug use. ${ }^{7}$ During childhood, the family is seen as having the primary influence on a child's behaviour, however, during adolescence and young adulthood this position is usurped by their peer group. Internationally, peer groups have been found to influence the initiation ${ }^{8}$ and maintenance of drug use, ${ }^{9}$ and the same outcomes are anticipated within a Jamaican sample.

Typically, spirituality is thought to act in a protective manner against drug use and therefore in many alcoholics anonymous (AA) groups, references to a greater power are entrenched in their twelve step program. ${ }^{10}$ Furthermore, the internalisation of spiritual beliefs may help to prevent drug use as spiritual doctrines typically prohibit drug use. However, alcohol is used within Catholic religious rituals and Jamaican Rastafarians use cannabis as a part of their spiritual practices. Nonetheless, spirituality is highly documented as acting in a protective manner against drug use. ${ }^{11}$

This research is part of a larger multi-country study involving universities from three Caribbean and five Latin American countries. This Jamaican segment focuses on assessing the relationship between family relationships, peer influence and spirituality on the drug use of students attending a selected university in Kingston, Jamaica. 


\section{METHODS}

This Jamaican segment of the multi-country research, employed a cross-sectional survey design to collect quantitative data from undergraduate tertiary students attending a selected university in Kingston, Jamaica. Power analysis $(>0.8)$ identified the minimum required sample size to be 250 and purposive sampling was utilised to collect data on undergraduate students, between the ages of 18 and 24 years. Students were required to be enrolled in one of the three pre-selected university faculties (Social Sciences, Medical Sciences, or Pure \& Applied Sciences).

The students completed a self-report questionnaire consisting of the Spiritual Involvement and Beliefs Scale (SIBS), the Alcohol, Smoking, and Substance Involvement Screen Test (ASSIST), the Peer Influence Scale (PIS), the Index of Family Relations (IFR) and a demographic questions.

The Spiritual Involvement and Beliefs Scale $(\mathrm{SIBS})^{12}$ was used to assess the extent to which the students identified with spiritual beliefs and behaviours. Spirituality for this study was defined as that which gives meaning to one's life and draws one to transcend oneself. It is a broader concept than religion, and is not associated with a particular religion or culture, but rather with spiritual expressions or behaviours, including prayer, meditation, interactions with others or nature, and relationship with God or a higher power. The SIBS, is a 26 item questionnaire with five potential likert responses ranging from $1=$ strongly disagree to $5=$ strongly agree. This scale has been found to demonstrate strong test-retest reliability $(\mathrm{r}=.92)$ and validity, as it was highly correlated $(\mathrm{r}=.80)$ with another benchmark measure of spirituality, the Spirituality Well-Being Scale. ${ }^{12}$

The Alcohol, Smoking, and Substance Involvement Screen Test (ASSIST) ${ }^{13}$ is a screening tool developed by the World Health Organisation to assess psychoactive substance use. The scale was found to have moderate $(\mathrm{r}=.58)$ to high $(\mathrm{r}=.90)$ test-retest reliability coefficients. ${ }^{13}$ The ASSSIT consists of 8 questions that measure the use, frequency of use, and the presence of risky substance use, for ten psychoactive substances. However, for this study only questions relating to the use of alcohol, cannabis and tobacco were utilised.

The Peer Influence Scale (PIS) ${ }^{14}$ was an adapted version of the Mayberry's Peer Influence Scale ${ }^{14}$ with an additional question being added to assess peer drug use. The added question was
"Most of my friends do not drink 5 or more drinks on one occasion". The resultant scale consisted of five items that measured the extent to which participants agreed or disagreed with statements about their peer's positive influence. Potential response choices ranged from $0=$ strongly agree to $3=$ strongly disagree. This scale was reversed scored, therefore higher scores indicated the presence of positive peer influence.

The Index of Family Relations (IFR), ${ }^{15}$ is a 25-item scale that measures the interconnectedness within a family. The IFR assesses the extent as well as magnitude of problems within a family, with higher scores representing a higher level of family problems. Each of the 25 items are measured along a seven-point scale, which ranges from $1=$ "none of the time" to $7=$ "all of the time." This scale seeks to control for response sets by wording half of the items in a positive manner, while the remaining items are worded negatively. The questionnaire was piloted prior to use to ensure that the items were being interpreted as intended, thereby preserving the integrity of the individual scales.

The data was cleaned and analysed using the Statistical Package for Social Sciences (SPSS) version 18. Descriptive as well as inferential statistics were conducted, namely frequencies and correlational analyses. The Ethics Committee of the selected university in Kingston, Jamaica as well as the CAMH Research Ethics Board, Toronto, Canada, both gave ethical approval for this study. Trained research assistants administered the questionnaires and the participants were all volunteers and no incentives were given.

\section{RESULTS}

The sample consisted of 335 students (69 $\%$ male and $31 \%$ female) with a mean age of 20.91 years $(S D=1.337)$, range 18-24 years. Drug use within the past year was reported by 77.6 $\%$ of the sample, with the most frequently used licit drug being alcohol $(77.9 \%)$ and the most frequently used illicit drug being cannabis (11.9\%). The presence of spiritual beliefs, that is a belief in a power greater than self, was reported by $88.8 \%$ of the students.

The quality of the student's family relationships and its relationship with alcohol, tobacco and cannabis use was investigated using the Spearman's Rho statistic. The results from these analyses are presented in Table 1. 
Table 1 - Correlation of stressful family relations and past year drug use. Kingston-Jamaica, 2011

\begin{tabular}{lccc}
\hline \multirow{2}{*}{ Type of drug used } & \multicolumn{3}{c}{ Stressful family relations } \\
& $\mathbf{n}$ & $\boldsymbol{r}_{\mathrm{s}}$ & $\boldsymbol{p}$ value \\
\hline Alcohol & 330 & .055 & .159 \\
Tobacco & 329 & -.006 & .459 \\
Cannabis & 326 & $.112^{*}$ & .021 \\
\hline${ }^{*}$ Correlation significant at $\mathrm{p}<.05$. & &
\end{tabular}

A significant positive correlation was identified between past year cannabis use and having dysfunctional and stressful family relationships. However, the quality of the students' family relationships, was not found to be significantly related to their use of alcohol or tobacco within the past 12 months.

The relationship between peer influence and drug use was also examined using the Spearman's Rho statistic. Peer influence was significantly correlated with both licit and illicit drug use. The use of alcohol, tobacco and cannabis was found to have a negative and significant correlation $(p<.05)$ with the presence of positive peer influences (see Table 2).

Table 2 - Correlation of positive peer influence and past year drug use. Kingston-Jamaica, 2011

\begin{tabular}{lccc}
\hline \multirow{2}{*}{ Type of drug used } & \multicolumn{3}{c}{ Positive peer influence } \\
& $\mathbf{n}$ & $\boldsymbol{r}_{\mathrm{s}}$ & $\boldsymbol{p}$ value \\
\hline Alcohol & 287 & $-.100^{*}$ & .047 \\
Tobacco & 283 & $-.115^{*}$ & .026 \\
Cannabis & 327 & $-.112^{*}$ & .030 \\
\hline
\end{tabular}

${ }^{*}$ Correlation significant at $\mathrm{p}<.05$.

An investigation of the association between spirituality and drug use also yielded significant correlations (see Table 3). The Spearman's Rho statistic highlighted a negative correlation between higher levels spirituality and the use of alcohol, tobacco and cannabis within the past 12 months $(\mathrm{p}<.01)$.

Table 3 - Correlation of spirituality and drug use within the past year. Kingston-Jamaica, 2011.

\begin{tabular}{lccc}
\hline Type of drug & \multicolumn{3}{c}{ Spirituality } \\
\hline Alcohol & $\mathbf{n}$ & $\boldsymbol{r}_{\mathrm{s}}$ & $\boldsymbol{p}$ value \\
Tobacco & 330 & $-.282^{*}$ & .001 \\
Cannabis & 329 & $-.153^{*}$ & .003 \\
\hline
\end{tabular}

${ }^{*}$ Correlation significant at $\mathrm{p}<.01$.

\section{DISCUSSION}

This research found that having positive family relationships did not influence the use of the licit drugs of alcohol and tobacco; as students with both cohesive as well as distant family relationships reported using these licit drugs within the past year. While positive family relationships acted in a protective manner against the use of the illicit drug, cannabis. Conversely, having distant family relationships may increase the risk of cannabis use; as the individual may feel emotionally distressed or isolated and may use cannabis to self-medicate their emotional distress. ${ }^{7}$

Since the family is nestled within the wider society, societal values would shape familial values. ${ }^{16}$ Therefore, a cohesive family would essentially, encourage its members to adhere to societal values; and for that reason having cohesive family relationships may act in a protective manner against illicit drug use, but would have a non-significant relationship with licit drug use. Therefore, the family would neither encourage nor act in protective manner against licit drug use.

Peer influence was significantly related to both licit and illicit drug use among this young adult population. Positive peer influence was a protective factor against any drug use, while negative peer influence appeared to have encouraged drug use. This finding was anticipated and is widely supported within the international literature. Some researchers have even postulated that the most significant interpersonal influence on drug use is that of one's peers. ${ }^{17}$ This association is clarified by the social learning theory, as it purports the premise that the drug attitudes and behaviours of an individual's peer group or role models will influence their own drug use. ${ }^{18}$

The university students in this sample were highly spiritual as 9 in every 10 students $(88.8 \%)$, reported a belief in a higher power. Spirituality has been identified in international research, as acting in a protective manner against any drug use. ${ }^{10}$ Conversely, lower levels of spirituality, were associated with drug use. This finding was anticipated as spiritual doctrines typically prohibit drug use and sometimes identifies drug use as being tantamount to a sin.

\section{CONCLUSIONS}

This study identified that a cohesive family relationship acts in a protective manner against cannabis use among tertiary students in one uni- 
versity in Kingston, Jamaica. Positive peer relations and high levels of spirituality were protective factors against the use of alcohol, tobacco and cannabis use among the students who participated in this research. Though these results cannot be generalised to Jamaican university students, because of the limited sampling technique employed, these findings highlight an area for further research to facilitate effective demand reduction strategies.

\section{Limitations}

This study provides valuable information regarding the influence of the family, peers and spirituality on drug use. However, the results must be interpreted with caution as a non-probability sampling technique was employed. Furthermore, the sample consisted of only university students, which is not representative of the typical Jamaican population; thereby challenging the ecological validity of this study.

\section{Recommendations}

Notwithstanding the limitations of the study, the results suggest that encouraging spirituality and having positive peer influences may reduce drug use among young adults in Jamaica. However, the way forward should be guided by empirical research conducted with a random sample. Hence, further research is required to support this premise.

\section{Acknowledgements}

This study was made possible due to the financial and technical support from the the Government of Canada/DFAIT, the Organization of America States (OAS), Inter-American Drug Control Commission (CICAD), and the Centre for Addiction and Mental Health (CAMH)- Toronto/ Canada. We would also like to thank the selected University in Kingston, Jamaica, other collaborators, as well as, the students who participated in this research.

\section{REFERENCES}

1. Whitcomb S, Merrell KW. Behavioral, social, and emotional assessment of children and adolescents. 4th ed. New York (US): Taylor \& Francis; 2013.

2. Jongsma AE, Peterson LM, Bruce TJ. The complete adult psychotherapy treatment planner. 4 th ed. New York (US): Wiley; 2012.
3. Eells TD. Handbook of psychotherapy case formulation. 2nd ed. New York (US): Guilford Publications; 2011.

4. Berman PS. Case conceptualization and treatment planning: integrating theory with clinical practice. 2nd ed. Thousand Oaks (US): SAGE Publications; 2009.

5. The National Council on Drug Abuse. National household survey of drug use and abuse in Jamaica, 2001. Kingston: The National Council on Drug Abuse ; 2002.

6. Leo-Rhynie EA. The Jamaican family: continuity \& change. Grace (US): Kennedy Foundation; 1993.

7. Davis DD. Terminating therapy: a professional guide to ending on a positive note. Hoboken (US): Wiley; 2008.

8. Gurman AS. Clinical handbook of couple therapy. 4th ed. New York (US): Guilford Publications; 2008.

9. Leiblum SR. Principles and practice of sex therapy. 4th ed. New York (US): Guilford Publications; 2006.

10. National Family Planning Board, United States Agency for International Development. Fact sheet: childhood and intimate partner violence in Jamaica. 2010 [cited 2013 Nov 25]; Available at: http:/ / www. jnfpb.org/factsheet/fact_sheet_draft.pdf

11. McKenzie K. Jamaica: community mental health services. In: Cohen A, Caldas de Almeida J, editors. Innovative mental health programs in Latin America \& the Caribbean: Pan American Health Organization; 2008. p. 79-92.

12. Hatch RL, Burg MA, Naberhaus DS, Hellmich LK. The Spiritual Involvement and Beliefs Scale. Development and testing of a new instrument. J Fam Pract. 1998 Jun; 46(6):476-86.

13. Greenberg N. Can spirituality be defined?. Knoxville (US): University of Tennessee; 2008.

14. WHO ASSIST Working Group. The Alcohol, Smoking and Substance Involvement Screening Test (ASSIST): development, reliability and feasibility. Addiction. 2002 Sep; 97(9):1183-94.

15. Corey MS, Corey GF. Groups: process and practice. 7th ed. Belmont (US): Thomson/Brooks/Cole; 2006.

16. Beck JS, Beck AT. Cognitive behavior therapy: basics and beyond. 2nd ed. New York (US): Guilford Publications; 2011.

17. Bronfenbrenner $U$. The bioecological model of human development. In: Bronfenbrenner $\mathrm{U}$, editor. Making human beings human: bioecological perspectives on human development. Thousand Oaks (US): Sage Publications; 2005. p. 3-15.

18. Nóbrega MPSS, Simich L, Strike C, Brands B, Giesbrecht N, Khenti A. Policonsumo simultâneo de drogas entre estudantes de graduação da área de ciências da saúde de uma universidade: implicações de gênero, sociais e legais, Santo André - Brasil. 
Texto Contexto Enferm [online]. 2012 [cited 2015

Jan 20]; 21(spe):25-33. Available at: http://www.

scielo.br/scielo.php?script=sci_arttext\&pid=S010407072012000500003\&lng=en\&nrm=iso

Correspondence: Samantha Longman-Mills

Faculty of Medical Sciences, Department of Community

Health \& Psychiatry

University of the West Indies, Mona

Kingston, Jamaica, West Indies

E-mail: samantha.longman02@uwimona.edu.jm 